\title{
The Seventh Congress of the Far Eastern Association of Tropical Medicine.
}

THE seventh Congress of the Far Eastern Association of Tropical Medicine was held in Calcutta on Dec. 5-24 last. The Association was founded at Manila in 1908, where the first congress was held in 1910. Since that date congresses have been held at intervals, usually of two years (except during and for a short interval after the War), at Hongkong, Saigon, Weltevreden, Singapore, and Tokyo. The Calcutta Congress was the largest that has so far been held, and was attended by about 900 members. The headquarters were in the School of Tropical Medicine and the adjacent Medical College.

The scientific business of the Congress was conducted in six sections: (i) Clinical medicine and surgery, ophthalmology, dermatology, etc. (apparently all that is not specifically included in the titles of the other sections); (ii) State medicine and hygiene, child welfare; (iii) plague, cholera, dysentery, sprue, intestinal infections, bacteriophage, leprosy, tuberculosis, and bacteriology; (iv) malaria, kala-azar, protozoology, typhus-like diseases, leptospiræ, medical entomology, and helminthology; (v) nutrition, deficiency and endocrine diseases, immunology, chemicotherapeutics, rabies, and pharmacology ; (vi) veterinary. Several of these were divided into subsections.

A total of 228 papers was read ; abstracts of these were published beforehand ${ }^{x}$ and were available for all members. Judging from these abstracts, the meetings of the sections must have been packed with interest. It is impossible to mention even a tithe of the titles that attract attention on turning over the pages of the handbook; and the following notes on a few of the papers are really only in the nature of a random sampling.

Dr. Gian Singh considered theincidence of pulmonary tuberculosis in Multan City, according to sex, religion, age, occupation, and residence in different parts of the city. His study leads him to recommend that Government should oblige municipalities to take housing schemes in hand, to open up congested areas, and to enforce building by-laws prohibiting high houses in narrow lanes; that municipalities should employ health visitors to carry on propaganda among the women against certain customs observed by them in the puerperal period; that the people themselves should form anti-purdah and anti-child marriage societies, and that the working and economic conditions of low-paid Government servants should be improved by Government.

Lieut.-Colonel Russell, considering population and public health in India, finds that the population is outrunning the means of subsistence, hence unemployment, rising prices, and reductions in the standard of living of agricultural and industrial workers. As to the possibility of these phenomena being countered by improved agricultural methods and the production of much larger quantities of food, the author considers it unlikely that the situation can be thus influenced to any extent in the long run. In the Madras Presidency the population is within a million of the upper asymptotic limit, and even now considerable quantities of rice are being imported from Burma and Ceylon.

Dr. d'Herelle has three papers on bacteriophage, a subject with which his name is especially connected, and which has attracted much interest in recent years. Bacteriophage is a 'principle' which effects the dis-

1 Guide to the Seventh Congress of the Far Eastern Association of Tropical Medicine, Calcutta, December 5th to 24 th, 1927. Pp. vi +115 . A bstracts of Papers and Programme of Scientific Sessions. Pp. iv + 176. The Indian Empire: being a Brief Description of the Chief Features of India and its Medical and Sanitary Problems. Pp. vii +346 +20 plates +4 maps. (Calcutta: Far Eastern Association of Tropical Medicine.)

No. 3044, VoL. 121] solution of bacteria, reproducing itself as it does so. According to d'Herelle, it is a filter-passing parasite (Protobios bacteriophagus d'Herelle 1918) of the bacteria. It is present in the intestine of every man and animal, and in normal individuals develops upon the saprophytic flora there present ; by a process of adaptation (demonstrable in vitro), which is more or less rapid according to circumstances, it becomes able to parasitise any invading bacteria. The end result, recovery or death, in the bacterial intestinal diseases of man and animals, depends on the power of the bacteriophage to attack and destroy the pathogenic organisms. Bacteriophagy is thus the result of an infectious disease prevailing amongst bacteria. Bacteriophage treatment has been eminently successful in bacillary dysentery, and in cholera has been fully efficient in the great majority of cases.

Lieut.-Colonel Acton and Major Chopra, investigating the action of quinine on the malarial parasites, found that by increasing the degree of alkalinity in the intestines they obtained a greater diffusion of quinine into the circulating blood; hence the blood concentration of quinine was higher when alkalis were administered at the same time. Still, the concentration attained in the circulating blood is considered to be insufficient directly to kill the parasites; but sublethal concentrations are able to paralyse their movements to a certain extent, and the parasites fail to penetrate the envelope of the red blood corpuscle and so to reach their food. These sluggish parasites are swept off the corpuscles by the friction of the blood stream and die of starvation.

Lieut.-Colonel Christophers and Dr. I. M. Puri ("Why do Anopheles Larvæ feed at the Surface, and How ?") show that the Anopheles larva is morphologically adapted to feed at the surface, and point out the advantages it obtains by doing so. (Most waters have a special bacterial and flagellate surface film; there is also a subsurface layer of organisms that aggregate below the surface film, either because they are lighter than water, or because they actively seek this position.) The feeding process is described.

Lieut.-Colonel S. P. James and Drs. Nicol and Shute consider the habits of Anopheles in relation to their rôle in the spread of malaria-an interesting paper, since the work was done in England, in connexion with the provision of supplies of infected mosquitoes for transmitting malaria to certain mental patients. The same authors have a paper on experiments on the treatment of malaria in England. Lieut.-Colonel James contributes some remarks on anti-malarial measures for poverty-stricken regions ; no one doubts, he says, the efficacy of the established methods of malaria control, but they are difficult and expensive, and it is important to discover a method which can be applied in poorer countries, such as those of southeastern Europe. In spite of the Commission appointed by the League of Nations Health Committee, such a method is not yet forthcoming; but the first aim should be to reduce the severity rather than the incidence, to combat the disease itself on its appearance in the human or insect hosts ; the disease then soon ceases to be of importance. Besides doing this by direct methods, it is essential to improve the economic and social conditions of the people and their general well-being and standard of life; Dutch and Italian schemes for such purposes are already in existence.

Lieut.-Colonel Knowles considers the kala-azar transmission problem and the factor of resistance ; he tells the interesting story of recent research into this problem, the arguments which led to the incrimination of the sandfly Phlebotomus argentipes as the trans- 
mitter, feeding experiments and their results, the working out of the history of the parasite in the fly (the whole life-cycle of the parasite is fully considered in a paper by Major Shortt), and refers to the parallel work of Patton and Hindle in China. The final link in the chain of proof, namely, transmission from man to a human volunteer by means of the sandfly, is still lacking, probably owing to the fact that man, instead of being very susceptible, is extremely resistant to infection by kala-azar.

There are numerous papers on helminthology and on medical entomology ; but these notes must close with a mention of Mr. Senior-White's paper on progress towards the realisation of the biological control of mosquito breeding, in which, after recounting the older methods, the author considers the connexion between the hydrogen-ion concentration of the water and the species of mosquitoes that breed in it. Acidity other than that due to carbon dioxide is definitely inhibitory to anophelines; but only extremes of 'natural' $p \mathbf{H}$ have any such effect. The presence of very small amounts of ammonia, however, are destructive to larvæ; and the probability that bacteriophages (v.sup.) can be isolated by which the nitrifying bacteria can be destroyed, and hence the conversion of ammonia into nitrites and nitrates delayed, gives a hope that practical measures may be devised on these lines.

Perhaps it is scarcely necessary to add that all the activities of the Congress were not on these strenuous lines. The programme specifies such things as an evening reception by H.E. the Governor of Bengal at Government House, another by the Trustees of the Indian Museum at the Museum, a conversazione by the Asiatic Society of Bengal, a garden party at Government House, river trips and 'bus tours, visits to works, scientific cinema films, a play in an Indian theatre, as well as other diversions. The scientific meetings concluded on Dec. 11, after which three tours were arranged, one through northern India, one through southern India (these lasting a fortnight), and one through Bihar and Orissa (lasting a week). The "Souvenir-The Indian Empire," presented to all members, is "a brief description of the chief features of India and its medical and sanitary problems"; it fulfils a similar function to the Local Handbook of the meetings of the British Association. Among its 18 chapters are included a résumé of Indian history, and accounts of the history of European medicine in India, of indigenous systems of medicine, of Indian archæology, zoology, botany, geology, weather, and art. Its 340 pages are illustrated by 20 plates of photographic reproductions, several - including the frontispiece, a magnificent peak in the Sikkim Himalayas of great beauty. Everything seems to have been done to make the Congress a success ; and the members can scarcely fail to have enjoyed an intensely interesting as well as a very profitable visit to Calcutta.
J. STEPHENSON.

\section{The Origin of the Japanese Earthquake of 1923.}

D. N. YAMASAKI, professor of geography in the Imperial University, Tokyo, contributed to the official report some valuable physiographic studies on the Japanese earthquake of 1923, which

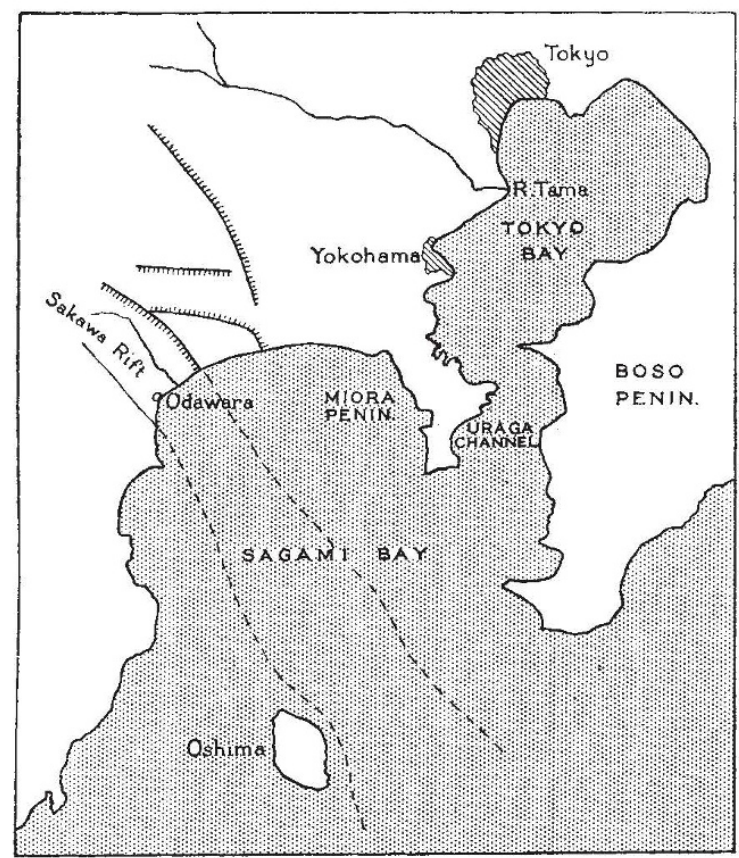

FIG. 1.

he has recently brought to the knowledge of western readers by translating them into English (Jour. Fac. Sci., Imp. Univ., Tokyo, vol. 2, pp. 77-119; 1926). They are of great interest, chiefly on account of the light which they throw on the origin of this remarkable earthquake.

No. 3044, Vor. 121]
The principal features of Prof. Yamasaki's map are here reproduced (Fig. 1). The river Sakawa runs into the Bay of Sagami on its north-west side. The valley is part of a remarkable rift valley, bounded on the north-east side by a fault-scarp from 200 to 300 metres in height. It was formed by blocking movements of comparatively recent date. Earthquakes, indeed, still occur in the district, one of the latest being the strong Odawara earthquake of 1633 . The earthquake of 1923 was very severe in this part. Many villages at the foot of the scarp were totally ruined and the level surface of the fields was thrown into gentle undulations. Still more remarkable than the rift valley on land is its continuation into Sagami Bay. A great trench runs along the axis of the bay in the direction S. $35^{\circ} \mathrm{E}$. Near the bottom of the trench the slope is gentle, while the straight side walls are steep and high. The north-east wall is an extension of the fault-scarp on the same side of the Sakawa valley, while the south-west wall is also a steep scarp passing a short distance to the east of the volcanic island of Oshima.

Before the earthquake of 1923, the depth of the trench varied from 1500 to 2000 metres. On the north-east side of the trench, the submarine plateau consists of two steps, the lower one $12 \mathrm{~km}$. wide at a depth of from 1000 to 700 metres, the upper one forming a shelf with a depth of less than 200 metres. One other feature deserves notice-a fiord-like furrow along the floor of the Uraga Channel, with a branch on the east continued into the Boso peninsula as the depressed tract around Tateyama.

The earthquake of 1923, in Prof. Yamasaki's opinion, may be considered as the direct effect of an enormous blocking movement in the district. The most remarkable displacement was of course that which occurred in Sagami Bay. The subsidence was greatest, from 100 to 210 metres, along the axis of the trench. The margin of the uplifted block on its north-east side was raised 250 metres, that on the south-west side 120 metres. Besides these tilted blocks in the deep sea, the shelf of land along the 